\title{
The Meaning of News Photos of the Islamic Defensive Action 411 and 212 in Harian Waspada
}

\author{
Topan Bilardo', Suwardi Lubis ${ }^{2}$, Syukur Kholil ${ }^{2}$ \\ ${ }^{1}$ Ph.D Student in State Islamic University of North Sumatera (UINSU), Medan, Indonesia \\ ${ }^{2}$ State Islamic University of North Sumatera (UINSU), Medan, Indonesia \\ tgkdrsaiful@gmail.com
}

\begin{abstract}
The development of photography both directly and indirectly is in line with the development of the journalistic field. Digital technology that is growing rapidly at this time also provides a significant contribution. Photos that record an event can be immediately disseminated in seconds using digital cameras and computer devices that have internet facilities. the photos that analyzed the meaning of photo denotations that appear such as mass mobilization, burning actions due to clashes between the masses and the police as well as photos of the Jakarta Governor's trial non-active Basuki Tjahja Purnama or Ahok reinforces the narrative that delivers news showing the two daily newspaper media giving support or partisanship to the actions of defending Islam 411 and 212. The meaning of connotations that appear in photographs can be seen from the photo taking process which generally from the upper and front sides of the object gives an impression of object density in the resulting image, further reinforcing the assumption of daily media alignment who only saw the Defensive Action of Islam 411 and 212 as a news commodity not a movement that defended the banners of Islam or defended a suspect in the religion, namely Basuki Tjahja Purnama or Ahok.
\end{abstract}

Keywords: Al Quran; Islamic Devensive Action; news photo; communication

\section{Introduction}

The function of photos in print media is not just an illustration of the news. However, the presentation of photos in newspapers has made the news complete, accurate and interesting. So that photos are channeling ideas, communicating with the community, influencing others, and presenting old memories. Photos in the mass media not only function as a complement to the message the communicator wants to convey, but it is the message itself. A photo presented in a newspaper (print mass media) is inseparable from journalistic goals, namely to spread the word as widely as possible.

Since photography was discovered in 1839 by French scientist, Louis Jacques Mande, in its development now, it has far left its early generation. Digital technology that is currently included in a number of human activities in their daily lives. One of them is in the world of photography. The presence of high-tech photography technology devices certainly has an effect on its output. The resulting photograph can be created or changed in such a way as the photographer wishes. With the power of authentic visualization, a photograph will be very representative used as a display of the objectives of journalistic activities.

The development of photography both directly and indirectly is in line with the development of the journalistic field. Digital technology that is growing rapidly at this time also provides a significant contribution. Photos that record an event can be immediately disseminated in seconds using digital cameras and computer devices that have internet facilities.

Journalistic photos are photos that contain news values that are factual in an event or event. The fact is basically something based on facts. The use of photos in newspapers is important for several reasons. First, the photo is the first element that catches the reader's eye. 
Second, photos in newspapers can be used to communicate with readers who have diverse backgrounds, because photos are universal ${ }^{1}$. Journalistic photos must include news value, completeness of photo text and have good aspects of photos. As with news, a journalistic photo must contain news value, it is intended so that a photo has an appeal to the audience. According to Professor of the University of Missouri, United States, USA, Cliff Edom, journalistic photos are a mixture of words and pictures (pictures). Meanwhile, according to the editor of Life magazine, Wilson Hicks, a combination of words and images that produce a unified communication when there are similarities between the educational background and the social readers.

Journalistic photos have five functions, first, to communicate the news (to communicate the news), photos often have very important meanings in delivering news. Photos can perfect a story, where without photos, news will feel bland. Second, the function of photojournalism is to generate interest (to generate interest). Third, journalistic photos serve to highlight the other dimensions of a shooting object that are published (to give another dimension to a newsworthy figure). Fourth, photojournalism serves to improve the news (the quality side of the news) without reducing the meaning of the news. And finally, journalistic photos are used for the general outline / appearance of newspapers and magazines. A journalistic photo can be said to be incomplete without a photo text. For this reason, photo text is needed to complete it. The effort to complete the $5 \mathrm{~W}$ and $1 \mathrm{H}$ elements is adjusted to the image displayed. Journalistic photos can be classified from the appearance of the photos made. World Press Photo (WPP) Foundation or the world photojournalism foundation in the Netherlands formulating types of journalistic photos. Photos of current events (spot news), photos of general events (general news), photos of nature, environment, flora and fauna (nature), portrait photos (portraits), photos of contemporary issues (contemporary issues), photos of humans on issues (people in the news), science and technology news, daily life photos, arts and culture photos, and sports news. Defense of Islamic Action is a series of demonstrations held in Indonesia, especially in the city of Jakarta in reaction to the statement of the Jakarta governor (Special Capital Region) Jakarta, BasukiTjahajaPurnama or Ahok who issued a statement deemed to be blasphemy in his working visit to the Thousand Islands.

\section{Literature Review}

\subsection{Communication Science Paradigm}

Berger and Chaffe in their 1987 Handbook of Communication Science wrote an understanding of the science of communication. Communication science is the science of production, process and influence of sign systems and symbols through the development of theories that can be tested and generalized with the aim of explaining phenomena related to the production, processes and effects of sign and symbol systems. The definition of communication science explained by Berger and Chaffee gives 3 (three) points of mind. First, the object of observation which is the focus of attention in the science of communication is the production, process and influence of systems of signs and symbols in the context of human life. Second, communication science is "scientific-empirical" (scientific) in the sense that the main points of thought in communication science (in theoretical forms) must be

\footnotetext{
${ }^{1}$ Flournoy, Don Michael,Analisis Isi Surat Kabar-Surat Kabar Indonesia.(Yogyakarta :Gadjah Mada University Press, 1989), p. 183.
} 
generally accepted. Third, communication explains social phenomena related to the production, process and influence of sign and symbol ${ }^{2}$ systems.

Intellectual tradition in question, namely: the way of looking at the world, or general way of thinking that is shared in the scientific community. This intellectual tradition that is more popular we find with the term paradigm (paradigm). Paradigms are the foundation (foundation) which becomes the basis of building a theory that is now starting to become familiar with us who are socializing in an academic environment. Paradigms play a very important role in determining the direction of the development of a science, including the science of communication. Paradigm, or how one views the world, influences the value, purpose, and style of scientific research.

In the Sociology community, the definition of paradigm that is widely used refers to the definition of George Ritzer. According to Ritzer in the book: Sociology A Multiple Paradigm Science (1975): a paradigm is a fundamental picture of the subject matter in a science. Paradigms help provide a definition of what must be learned, what questions should be raised, how the questions are raised, and what rules must be obeyed in interpreting the answers obtained. Paradigm is the most extensive consensus in a science and helps distinguish one scientific community (or subcommunity) from another. The paradigm includes, defines, and connects copies, theories, methods, and instruments in it.

Denzin\& Lincoln defines the paradigm as: "Basic belief systems or world guides that are investigators, not only in choices of methods but in ontologically and epistemologically fundamental ways. ${ }^{13}$ Understanding that contains the meaning of paradigms is a basic belief system or a way of looking at the world that guides researchers not only in choosing methods but also fundamental ways that are ontological and epistemological. Briefly, Denzin\& Lincoln defines "Paradigm as Basic Belief Systems Based on Ontological, Epistemological, and Methodological Assumptions." "Paradigms are basic belief systems based on ontological, epistemological, and methodological assumptions. Denzin\& Lincoln stated: "A paradigm may be viewed as a set of basic beliefs (or metaphysics) that deals with ultimates or first principle.". A paradigm can be seen as a set of basic beliefs (or those that are behind the physical, metaphysical) that are main principle or principle.

Kuhn called this paradigm change a scientific revolution. In the tradition of communication science itself, there has not been a scientific revolution that answers the problems of the times that are always renewed by development and technological development. Realities of communication are still seen using glasses or paradigms that are already obsolete.

\section{Classical Paradigm}

This paradigm places the social sciences like the physical sciences. Placing social science as an organized method for combining deductive logic with empirical observation. Aim to find a causal relationship that can be used to predict general patterns of certain social symptoms.

\footnotetext{
${ }^{2}$ Sendjaya, Sasa Djuarsa Dkk, Teori Komunikasi. (Jakarta : Universitas Terbuka, 2007), p. 10.

${ }^{3}$ Denzin \& Lincoln,Hand Book Of Qualitative Research, Sage Publication. Thousan Oaks.London, 1994),.p. 105.

${ }^{4}$ Ibid, p. 107
} 


\section{Constructivism Paradigm}

This paradigm views social science as a systematic analysis of socially meaning action. Science is obtained through direct and detailed observation of social behavior in a natural, everyday atmosphere, in order to be able to understand and interpret how the social actors concerned create or manage their social world.

\section{Critical Paradigm}

This paradigm defines science as a process that critically tries to uncover "the real structures" behind the illusion or false consciousness that is revealed on the surface. Aims to help form a social awareness so that someone or society can improve and change their living conditions.

\subsection{Mass communication}

Mass communication, like other forms of communication (interpersonal communication, group communication or organizational communication), has at least six elements, namely communicator, (messenger), message, media, communicant (recipient of the message), effects and feedback.

The definition of mass communication that is more detailed is addressed by communication expert Gerbner. According to Gerbner (1967) "Mass communication is the technologically and institutionally based production and distribution of the most broadly shared continuous flow of industrial societies". (Mass communication is production and distribution based on technology and institutions of continuous message flow and the most widely owned by people in industrial societies ${ }^{5}$. From the definition of Gerbner, it is illustrated that mass communication produces a product in the form of communication messages. The product is distributed, distributed to a wide audience.

Mass communication according to Freidson is distinguished from other types of communication by the fact that other communication with a fact that mass communication is addressed to a number of populations from various groups, and not just one or several individuals or a particular part of the population. Mass communication also has an implicit assumption that there are special tools to convey communication so that communication can be achieved at the same time all people representing various layers of society.

For Freidson, a large and dispersed audience is expressed as a number of populations, and the population is a representation of various layers of society. This means that the message is not only intended for a certain group of people, but for everyone. This is actually the same as the open term from Meletzke. Freidson can show the characteristics of other mass communication, namely the element of simultaneous acceptance of messages by the communicant, the message can reach at the same time to all people who represent various layers of society. Listening to the various definitions of mass communication put forward by communication experts, there seems to be no fundamental difference or principle, even those definitions complement each other. This gives a clear picture of the notion of mass communication.

\subsection{Semiotics}

Semiotics is a science or method of analysis to examine signs. Signs are devices that we use in an effort to try to find a way in this world, in the midst of humans and with humans.

\footnotetext{
${ }^{5}$ Rakhmat, Jalaludin, Psikologi Komunikasi, (Bandung : Remaja Rosdakarya, 2003), p. 188.

${ }^{6}$ Kurniawan. Semiologi Roland Barthes. (Magelang. Indonesia Tera.2001), p 53
} 
Semiotics or in Barthes's terms is semiology, basically wants to learn how humanity uses things (things), uses (to signify) in this case cannot be mixed by communicating (to communicate). Meaning means using objects not only carrying information, in the case where objects suddenly communicate, but also constituting a structured system of signs ${ }^{6}$. Roland Barthes was a structuralism thinker who practiced Saussure an linguistic and semiological models. Barthes is also known as a famous French intellectual and literary critic; exponents of the application of structuralism and semiotics to the study of literature.

One of the areas Barthes encroached in his study of signs was the reader. The connotation, even though it is the original nature of the sign, requires active readers to function. Barthes at length reviews what is often referred to as the second level meaning system, which is built on other existing systems. This second system by Barthes is called connotative, which in his Mythologies he expressly distinguishes from denotative or first level system of meaning. Continuing the study of Hjelmselv, Barthes created a map of how signs work

\subsection{Photography}

Anyone can take pictures with the addition of creative thoughts and hard work, we can create great images that show all the creations and interpretations of what is seen and taken. Well, the art of capturing images using a camera is called Photography. Photography comes from Latin, namely: photos are light, light. Graphein means writing, drawing or form design. So, photography is broadly writing or drawing using light. Dead images or paintings obtained through the irradiation process using light. Because in making our images using a tool called a camera, then of course we must really master the tool, including some basic techniques.

\section{Discussion}

\subsection{HarianWaspada Saturday Edition $5^{\text {th }}$ November 2016 "MASS"}

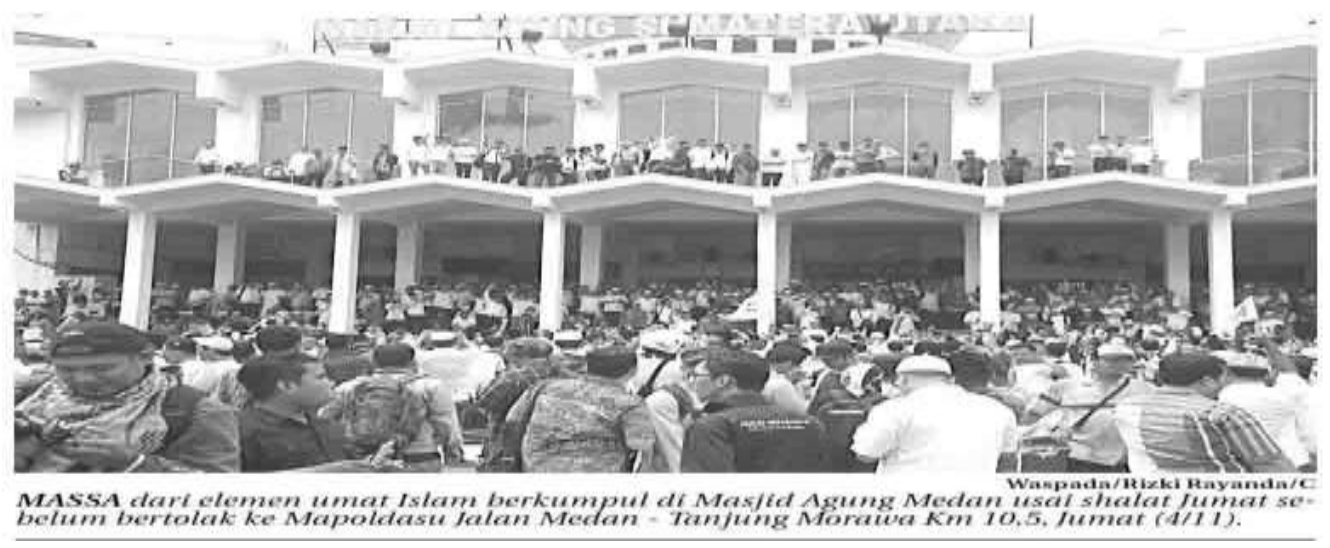

Photo Title: Thousands of people from Muslim Community gathered at Medan Grand Mosque after Friday prayers before leaving for MapoldasuJalan Medan TanjungMorawa Km 10.5, Friday (4/11). (Alert / Rizki Rayanda)
Media
: HarianWaspada
Edition
: Saturday $5^{\text {th }}$ November 2016 


\section{Page : A2}

\section{Figure 4.13 : Mass Denotation}

In this photo, a symbol or denotation meaning is a photo taken on Friday 4 November 2016, seen thousands of protesters from various elements of Islamic ummah were seen gathering in front of the courtyard of the Great Mosque of Medan. Above the roof of the mosque is the inscription of the Great Sumatra North Mosque as the name of the mosque On the outside of the mosque roof a number of people were seen up there who were standing and some were squatting while looking at a crowd of people under it and in the mosque there was a crowd of protesters standing up and moving towards the North Sumatra Regional Police Headquarters for a peaceful protest. At the bottom left corner of the photo is a photographer wearing a hat in an upside down position looking at his camera.

\section{Connotation}

In taking pictures, it is also necessary to edit or do image manipulation. So that it will make the photo better, and can even give the impression or message that you want to convey in the photo. First, it will be discussed for trick effects (photo manipulation) such as adding, subtracting, or changing a photo. In the photo above it can be seen if photo manipulation such as reducing, adding, or changing objects is not done. Second, poses, namely gestures, attitudes and expressions of objects that are based on a particular society and have certain meanings. In this photo, there are poses by thousands of protesters at the Medan Grand Mosque. RizkiRayanda from the Waspada news agency who took this picture tried to convey the atmosphere of the protestors' message after performing Friday prayers at the Medan Grand Mosque before holding a demonstration at the North Sumatra Regional Police Headquarters.

Third, objects are objects or objects that are composed in such a way that they can be associated with certain ideas. The object in this photo is the mass of protesters who will take a peaceful action at the North Sumatra Regional Police Headquarters. Fourth, photogenia is the art of photographing, so that the resulting photo has been "spiced" or decorated with ligthing, exposure, and printing techniques. In a photo it takes a technique to take pictures so that you can get good and beautiful images. The techniques that exist in the world of photography are lighting or lighting techniques. Researchers see only with the help of natural light from sunlight as a source of light, because shooting is done during the day, there is no flash, fill in light or background light, because the light needed by the camera is still very sufficient. For the focus point of the lens on the reporter's camera, it rests on the middle of the crowd at the Great Mosque of Medan. In principle, color is one of the important elements in photography. Color responds to the eye and stimulates the taste. Color makes emotional stimulation, therefore each person has a different color feel. Color choices have a direct influence on the perception of seeing. Color is also a symbol and symbol of something and presents identification with something.

Photos are printed in BW (Black and White) format, the advantages in BW (Black and White) photos in photos are very significant, BW photos (Black and White) can bring into deep feeling situations when viewing the photo. As far as the manipulation of color changes from RGB (Red-Blue-Green) to BW (Black and White) and the composition in the photo there is no problem because the most important element of information and education reaches. Black and white photos do not really contrast black and white. Black and white are combined in one continuum which produces a series of gray shadows. Many prints, including those made at the beginning of the development of photography, were given a hue of sepia 
(for archival stability) that had a richer and shadier shadow than reproduction in black and white. Color photography gives more color choices, but the advantages of black and white photography are the softer monochromatic characters. Fifth, aestheticism or aesthetics is related to the composition of the overall picture which gives a certain meaning. The photo, also taken in a wide angle with the camera position horizontally, because the photographer wants to capture the atmosphere of thousands of protesters who defend Islam in the Great Mosque of Medan. Sixth, syntax is usually present in a series of photos displayed in one title, where time does not appear in each photo, but for the entire photo displayed, especially when associated with the main title. In this photo, the researcher analyzes based on what is listed in the photo caption. Syntax (syntax) itself can be analyzed through coherence, sentence form, and pronouns.

Based on the Caption contained in the photo telling the masses or groups of Muslim elements gathered at the Medan Grand Mosque after Friday prayers will hold a demonstration that will take place at the North Sumatra Regional Police Headquarters (Mapoldasu) Jalan Medan - TanjungMorawa Km 10.5,

\section{Myth}

Barthes's perspective on myths is one of the characteristics of his semiology which opens up a new realm of semiology, namely the further excavation of marking to achieve myths that work in the daily reality of society. In this photo there is a myth contained in it, and in this photo the myth that is seen is the gathering of Muslims in the mosque before taking a peaceful action against Islam. The mosque is a place (building) whose main function is as a place of prayer to worship Allah SWT. The Word of Allah SWT in Surat al-Jin verse 18:

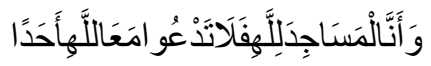

Meaning: "And indeed the mosques belong to Allah. So do not worship anyone in it beside Allah?

Besides being a place of worship for Muslims in a special sense (mahdhah), the mosque is also a place of worship widely (ghairumahdhah) as long as it is carried out within the boundaries of the Shari'ah. A large, beautiful and clean mosque is our dream, but it is not enough if it is not supported by the mosque's ${ }^{8}$ prosperity activities. The mosque is a spiritual pillar that supports the worldly life of the people. The mosque reflects all the activities of the ummah, the mosque becomes a measure and an indicator of the well-being of both the spiritual and spiritual people. Therefore, if there is no mosque in the area that has a population of Islam or there is a mosque in the middle of the population of Islam, but it is not used as a center of life for the people, this will be a negative sign of the orientation of the people's life. In these two situations, people will experience confusion and suffer from various mental and physical ailments and cannot enjoy the distribution of pleasure and energy from Allah SWT.

\footnotetext{
${ }^{7}$ QS. Surat al-Jin, ayat 18, Lihat: Departemen Agama RI, “Al-Qur"an dan Terjemahannya”, (Bandung: PT Sygma Examedia Arkanleema, tt,) page. 573

${ }^{8}$ Sidi, Gazalba, Masjid Pusat Ibadat dan Kebudayaan Islam,(Jakarta: Pustaka Antara ,1971), page 27

${ }^{9}$ Sidi, Gazalba, loc.cit, page. 145
} 
Mosques at the time of the Prophet were very simple, but with their simplicity, the mosque had many functions and roles to play. Most of the life of the Prophet is in the mosque environment, besides living in the mosque environment, he is also often in the mosque if there are no important activities that make it out, and make the mosque a center of da'wah, the center of worship (mahdhah and ghairumahdhah), community center, community education and development center, government center, military command center, information center, consultation center, mental rehabilitation center, center of remembrance, and many others. In this simple mosque ${ }^{9}$ the Prophet began to mobilize strength. Consolidating Muslims with the Muakhat movement (unifying, Muhajirin and Ansar). Capitalizing on this small mosque building, the Prophet began to build the world, so that the small city where he built the world truly became Medina, whose meaning was "the center of civilization", or at least, from that place the seed of a new civilization was born.

\subsection{Harian Waspada Edition Tuesday $5^{\text {th }}$ November 2016 "MASS"}

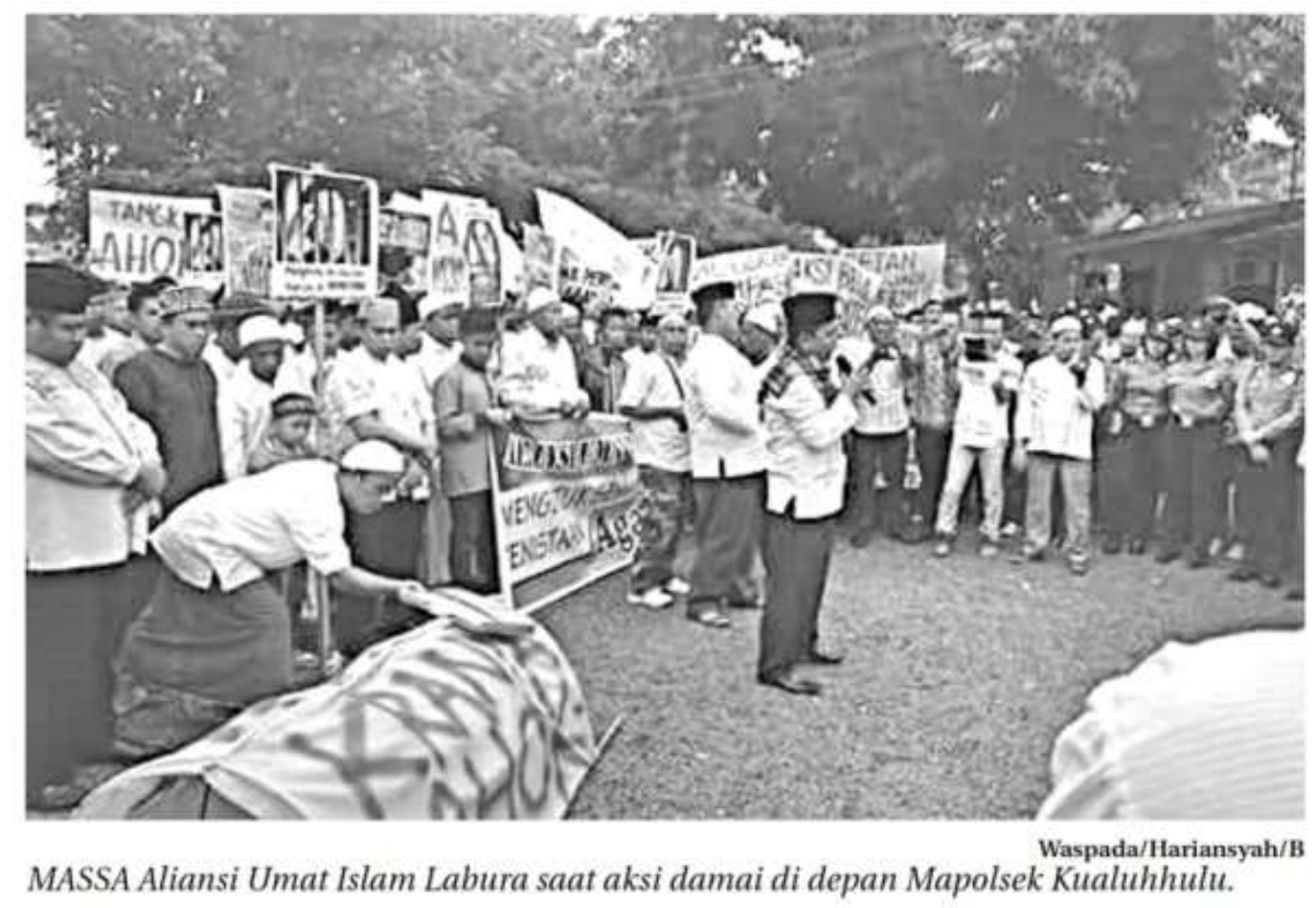

Photo Title : MASSA Labura Muslim Alliance during a peaceful protest in front of Kualuhhulu Police Headquarters. (Waspada / Hariansyah)

$\begin{array}{ll}\text { Media } & \text { : Harian Waspada } \\ \text { Edition } & \text { : Saturday } 5^{\text {th }} \text { November } 2016 \\ \text { Page } & \text { : B6 } \\ \text { Figure 4.14 } & \text { : Mass Denotation }\end{array}$

In this photo, a marker or denotation meaning is a photo taken on Friday, November 4, 2016, seen by demonstrators in a peaceful action against Islam carried out by the Labura (North Labuhan Batu) alliance when in front of Kualuhhulu's Police Headquarters (Sector 
Police Headquarters). In the middle of the photo, one of the action coordinators was holding a microphone with his right hand conveying his aspirations in front of Kualuhhulu Police Headquarters. To the right of the photo, a blockade was carried out by the Police of the Women (Polwan) from the Mapolsek Kualuhhulu. On the left side of the photo, protesters carry posters that read Ahok capture and pictures of the Jakarta Governor (Special Capital Region) Jakarta is off Basuki Tjaahja Purnama or Ahok who is holding his forehead with a foreground as a symbol of tahana. While on the lower left side of the photo there is a sign of a corpse that reads the sign of Ahok.

\section{Connotation}

In taking pictures, it is also necessary to edit the process or do image manipulation. So that it will make the photo better, and can even give the impression or message that you want to convey in the photo.

First, it will be discussed for trick effects (photo manipulation) such as adding, subtracting, or changing a photo. In the photo above it can be seen if photo manipulation such as reducing, adding, or changing objects is not done. Second, poses, namely gestures, attitudes and expressions of objects that are based on a particular society and have certain meanings. In this photo, the pose performed by the protesters in the Kualuhhulu police station.

Hariansyah from the Waspada news agency who took this picture tried to convey the message of the atmosphere of the protesters from the Labuhan Batu Utara Muslim alliance (Labura) carrying out a peaceful protest against Islam in front of Kualuhhulu Police Headquarters.nThird, objects are objects or objects that are composed in such a way that they can be associated with certain ideas. The object in this photo is the mass of protesters who will hold a peaceful action in front of Kualuhhulu Police Headquarters. Fourth, photogenes is the art of photographing, so that the resulting photo has been "spiced" or decorated with lighting, exposure, and printing techniques. In a photo it takes a technique to take pictures so that you can get good and beautiful images. The techniques that exist in the world of photography are lighting or lighting techniques. Researchers see only with the help of natural light from sunlight as a source of light, because shooting is done during the day, there is no flash, fill in light or background light, because the light needed by the camera is still very sufficient. In principle, color is one of the important elements in photography. Color responds to the eye and stimulates the taste. Color makes emotional stimulation, therefore each person has a different color feel. Color choices have a direct influence on the perception of seeing. Color is also a symbol and symbol of something and presents identification with something.

Photos are printed in BW (Black and White) format, the advantages in BW (Black and White) photos in photos are very significant, BW photos (Black and White) can bring into deep feeling situations when viewing the photo. As far as the manipulation of color changes from RGB (Red-Blue-Green) to BW (Black and White) and the composition in the photo there is no problem because the most important element of information and education reaches. Black and white photos do not really contrast black and white. Black and white are combined in one continuum which produces a series of gray shadows. Many prints, including those made at the beginning of the development of photography, were given a hue of sepia (for archival stability) that had a richer and shadier shadow than reproduction in black and white. Color photography gives more color choices, but the advantages of black and white photography are the softer monochromatic characters. 
Fifth, aestheticism or aesthetics is related to the composition of the overall picture which gives a certain meaning. Photos, also taken in a wide angle with the camera position horizontally, because the photographer wanted to capture the atmosphere of the protesters in the act of defending Islam in front of the Kualuhhulu Police Headquarters. Sixth, syntax is usually present in a series of photos displayed in one title, where time does not appear in each photo, but for the entire photo displayed, especially when associated with the main title. In this photo, the researcher analyzes based on what is listed in the photo caption. Syntax (syntax) itself can be analyzed through coherence, sentence form, and pronouns.

Based on the Caption contained in the photo, it tells the masses or groups who are members of the Labura (North Labuhan Batu) alliance during a peaceful demonstration in front of Kualuhhulu Police Headquarters related to blasphemy by the Governor of DKI Jakarta Basuki Tjahja Purnama or Ahok.

\section{Myth}

After the researcher looked at and analyzed the photo above, the first stage of the sign was in accordance with the map of the sign from Roland Barthes, then the researcher proceeded to map the sign of the second stage which contained a myth

\section{Conclusion}

From the photos that analyzed the meaning of photo denotations that appear such as mass mobilization, burning actions due to clashes between the masses and the police as well as photos of the Jakarta Governor's trial non-active Basuki Tjahja Purnama or Ahok reinforces the narrative that delivers news showing the two daily newspaper media giving support or partisanship to the actions of defending Islam 411 and 212. The meaning of connotations that appear in photographs can be seen from the photo taking process which generally from the upper and front sides of the object gives an impression of object density in the resulting image, further reinforcing the assumption of daily media alignment who only saw the Defensive Action of Islam 411 and 212 as a news commodity not a movement that defended the banners of Islam or defended a suspect in the religion, namely Basuki Tjahja Purnama or Ahok. Although the photo appeared a condition with the meaning of myth as developed in the semiotic model Roland Barthes be i reference in this study, but the meaning of the myth was accidentally formed by photo reporters whose photos were published from the Analysis and Alert daily, the object taking angle sought was only to dramatize the photos produced.

\section{References}

Abdurahman, Kedahsyatan Bersedekah, Yogyakarta: Pustaka Rama, 2010.

Ahmad Syauqi Al-Fanjari, Nilai Kesehatan Dalam Syariat Islam, Jakarta: Bumi Aksara, 1996.

Andrew, Tolson. Mediation: Text and Discourse in Media Studies. London: Arnold. 1996

Ardianto, Komala dan Siti Karlinah. Komunikasi Massa : Suatu Pengantar. Bandung: Simbiosa Rekatama Media. 2007.

Arif Sumantri, Kesehatan Lingkungan, Jakarta: Kencana Prenada Media Group, 2010.

Arifin, Anwar, Strategi Komunikasi: Suatu Pengantar Ringkas, Bandung:Armico. 1984. 
Asep Syamsul M. Romli. Jurnalistik Terapan Dan Kepenulisan, Bandung : BATIC PRESS, 2002.

Barthes, Roland. Image, Music, Text."The Photographic Message."Ed. and trans. Stephen Heath. New York: Hill. 1977.

Berger, Arthur Asa. Media Analysis Techniques. California: Sage Publications, 1982. Media Analysis Techniques, Yogyakarta, Universitas Atma Jaya. 1999.

Budiman Mustofa, Manajemen Masjid Gerakan Meraih Kembali Kekuatan Masjid dan Potensi Masjid. Solo: Ziyad Visi Media, 2007.

Bungin, Burhan. Sosiologi Komunikasi (Teori, Paradigma, dan Discourse. Teknologi Komunikasi di Masyarakat). Jakarta: Kencana Prenada Media 2008.

Cangara, Havied. Pengantar Ilmu Komunikasi. Jakarta : Raja Grafindo Praha. 2002.

Christomy, T dan Untung Yuwono. Semiotika Budaya. Jakarta: Pusat Kemasyarakatan dan Budaya UI. 2004.

Denzin \& Lincoln, Hand Book of Qualitative Research, Sage Publication. Thousan Oaks. London. 1994.

F. Rachmadi. Perbandingansistem Pers. Jakarta: Gramedia. 1990.

Fajar, Dadang Ahmad. Epistimologi Doa. Bandung : Nuansa. Cendikia. 2011.

Flournoy, Don Michael. Analisis Isi Surat Kabar-Surat Kabar Indonesia. Yogyakarta : Gadjah Mada University Press. 1989.

Fiske, John. Cultural And Communication Studies :Sebuah Pengantar Paling Komprehensif. Yogyakarta: Jalasutra. 2004.

Cultural and Communication Studies. Yogyakarta : Jalasutra. 2007.

George Ritzer-Douglas J. Goodman, (printed.3), Teori Sosiologi Modern, sixth edition, Jakarta, Prenada Media. 2003,

Hamad, Ibnu, Konstruksi Realitas Politik Dalam Media Massa, Jakarta, Granit. 2004.

Hamid, Usman. Menatap Wajah Korban. Jakarta, Solidaritas Nusa Bangsa, 2005.

Hasbiyallah, Fiqh dan Ushul Fiqh, Bandung: PT Remaja Rosdakarya, 2013.

Ibnu Rif ah Ash-shilawy, Panduan Lengkap Ibadah Shalat, Yogyakarta: Citra Risalah, 2009.

Junaidi, Kurniawan. Ensiklopedi Pers Indonesia. Jakarta : Gramedia. 1991.

Khairunnas Rajab, Psikologi Ibadah, Jakarta: Amzah, 2011.

Kotler, Philip dan Kevin Lane. 2009. Manajemen Pemasaran. Vol.1. Edition.13, Jakarta : Erlangga, 2009.

Kurniawan.Semiologi Roland Barthes. Magelang.Indonesia Tera. 2001.

Kusumaningrat, Hikmat dan Purnama Kusumaningrat. Jurnalistik, Teori dan Praktis. Bandung: PT Remaja Rosdakarya, 2005.

Kriyantono, Rachmat. Teknik Praktis Riset Komunikasi. Jakarta: Kencana. 2007.

Lexy J. Moleong, Metodolagi Penelitian Kualitatif, Bandung: PT. Remaja Rosda. Karya, 2005.

Littlejohn, Stephen W. Theories of Human Communication, Belmont, California: Wadsworth Publishing Company. 1999,

Teori Komunikasi, edisi 9. Jakarta: Salemba Humanika. 2009.

M.Quraish Shihab, Tafsir al-Mishbah Pesan, Kesan, dan keserasian al-Qur'an, Volume 2, Printed 1, Ciputat: Lentera Hati, 2000.

Mahmud Junus, Al Qur'an Al Karim, Bandung: PT Al-Ma'arif, 1986.

Matsumoto, D. Pengantar Psikologi Lintas Budaya., Yogyakarta: Pustaka Pelajar. 2004. 
McQuail, Teori Komunikasi Massa ed. 2, Jakarta: Erlangga. 1987.

Muhammad Bagir, Fiqih Praktis I: Menurut Al-Qur"an, As-Sunnah dan Pendapat Para Ulama, Bandung: Penerbit Karisma, 2008.

Muhammad Said Mursi, Seni Mendidik Anak, Jakarta: Pustaka Al-Kautsar, 2001.

Miles, Matthew dan Huberman, A. Michael.Analisis Data Kualitatif: Buku Sumber Tentang Metode-Metode Baru. Jakarta:UI Press. 1992.

Moh Ayub, Manajemen Masjid Petunjuk Praktis bagi Para Pengurus, Jakarta: Gema Insani, 1996.

Mulyana, Deddy. Ilmu Komunikasi: Suatu Pengantar. Bandung: Remaja Rosdakarya. 2004.

Nawawi, Hadari. Metode Penelitian Bidang Sosial. Yogyakarta ; Gajah Mada Univercity Press. 1995.

Nurudin, Komunikasi Massa, Malang: CESPUR. 2003.

Sistem Komunikasi Indonesia. Jakarta : Rajawali Pers, 2004.

Paul Colbey \& Litza Jansz.Introducing Semiotics. NY: Totem Books. 1999.

Phelan, Michael P. And Scott A. Hunt. Prison Gang Members's Tatoos as identity Work: The Visual Communication of Moral Careers. University of Kentucky. 1998.

Philip K. Hitti, History of the Arabs: from the Earliest Times to the Present. Translated by R. Cecep Lukman Yasin and Dedi Slamet Riyadi Jakarta: Serambi Ilmu Semesta, 2010.

Rakhmat, Jalaludin.Metode Penelitian Komunikasi. Bandung: PT Remaja Rosdakarya, 1997. Psikologi Komunikasi, Bandung : Remaja Rosdakarya, 2003. Metode Penelitian Komunikasi. Bandung: P.T. Remaja Rosdakarya. 2004.

Robert H. Thouless, Pengantar Psikologi Doa, Printed III, Jakarta: Raja Grafindo Persada, 2000.

Said bin Ali bin Wahf Al-Qahthani, Lebih Berkah Dengan Sholat Berjamaah, terj. Muhammad bin Ibrahim, Solo: Qaula, 2008.

Sayyid Sabiq, Fikih Sunnah 1, translated by Mahyudin Syaf, Bandung: PT Alma arif, 1973.

Sendjaya, Sasa Djuarsa. Pengantar Komunikasi. Jakarta : Universitas Terbuka. 1993.

and Hendra Harahap, Proses dan Dinamika Pemberitaan Televisi pada Mei 1998, in Dedy N. Hidayat at all, Pers in "Revolusi Mei" runtuhnya Sebuah Hegemoni, Jakarat: Gramedia,2000. at all. Teori Komunikasi. Jakarta : Universitas Terbuka. 2007.

Sidi, Gazalba, Masjid Pusat Ibadat dan Kebudayaan Islam, Jakarta: Pustaka Antara ,1971.

Silalahi, Ulber. Metode Penelitian Sosial. Bandung; PT. Refika Aditama, 2009.

Singarimbun, Masri. Metode Penelitian Survey. LP3ES. Jakarta. 1995.

Sobur, Alex, Analisis Teks Media. Bandung : PT. Remaja Rosdakarya. 2001.

Sunardi, St. Semiotika Negativa. Yogyakarta: Buku Baik. 2004.

Syahidin. Menelusuri Metode Pendidikan dalam Al-Qur'an. Bandung: Alfabeta, 2009.

Walter Ullman, Law and Politics in the Middle Ages Cambridge: Cambridge University Press, 1975.

Wiryanto, Pengantar Ilmu Komunikasi, Jakarta: Gramedia Widiasarana Indonesia. 2005,

Yusuf Al-Qaradhawi, Fiqih Peradaban: Sunnah Sebagai Paradigma Ilmu Pengetahuan. Translated by Faizah Firdaus. S 